\title{
Ranking of By-products for Single Cell Oil Production. Case of Latvia
}

\author{
Elīna RAČKO ${ }^{1 *}$, Dagnija BLUMBERGA ${ }^{2}$, Krišs SPALVIN̦Š $^{3}$, Eglè MARČIULAITIENË ${ }^{4}$ \\ ${ }^{1-3}$ Institute of Energy Systems and Environment, Riga Technical University, 12-k1 Äzenes iela, Riga, \\ LV-1048, Latvia \\ ${ }^{4}$ Research Institute of Environmental Protection, Vilnius Gediminas Technical University, \\ Sauletekio al. 11, 10223 Vilnius, Lithuania
}

\begin{abstract}
Single cell oil is considered as a promising alternative to fish and vegetable oils. Due to the ability of oleaginous microorganisms to produce significant amounts of polyunsaturated fatty acids such as docosahexaenoic acid (DHA) and eicosapentaenoic acid (EPA), single cell oil can be used for human and animal consumption. In this context, marine microorganisms of the class Labyrinthulomycetes are particularly highlighted in scientific literature. In order to clarify the possibilities for the use of microorganisms of the class Labyrinthulomycetes in large-scale single cell oil production, the first step is to gain awareness of the cultivation conditions required for these microorganisms. In addition, to reduce the cost of single cell oil production, it is necessary to identify potential agroindustrial waste products that are suitable for microbiological cultivation of Labyrinthulomycetes. This article examines the potential biotechnological applications of Labyrinthulomycetes in single cell oil production, the cultivation conditions, nutritional requirements, inhibitors and suitable waste products. In addition, an agroindustrial by-product availability analysis has been carried out. The article evaluates agroindustrial byproducts based on their availability in Latvia, required pre-treatment, price, shelf life and efficiency.
\end{abstract}

Keywords - Biotechnology; high value-added product; Labyrinthulomycetes; TOPSIS

\section{INTRODUCTION}

The world population growth as well as the rise in global awareness among consumers regarding healthy lifestyles and health benefits of omega-3 fatty acids contributes to the increasing consumption of fish products. This factor impacts the expansion of the aquaculture industry, which is followed by the need for an economically viable, sustainable and renewable source of fish feed in order to obtain high quality and nutrient rich fish with large live weight. Although the aquaculture industry contributes to reducing the burden on wild fish resources, fish oil and fishmeal derived from wild fish are widely used in the aquaculture industry as a fish feed ingredient, making this industry dependent on wild capture fisheries [1]. Also the demand for fish oil for human consumption is expected to grow rapidly (estimated growth rate by almost $80 \%$ in the period 2015-2025) [2]. Fig. 1 shows the global trend in fish oil consumption [2]. The demand for fish oil in aquaculture will grow more slowly as the industry is expected to be forced to use other alternatives, nevertheless, aquaculture consumption will increase by $17 \%$ [2]. Based

\footnotetext{
* Corresponding author.

E-mail address: eliinaracko@gmail.com

C 2020 Elīna Racko, Dagnija Blumberga, Krišs Spalvins, Eglè Marciulaitiene. 
on projections shown in Fig. 1, by 2025 about twice as much fish oil (compared to 2014) will be needed to provide both humans and aquaculture with the essential omega- 3 fatty acids.

Traditional fish feed ingredients such as fishmeal and fish oil are effective, but their extraction from wild fish is limited. Historically one of the most used alternatives is vegetable oil. However, vegetable oils cannot be considered as a sustainable substitute, due to competition for these resource between two sectors - animal feed production and human functional food production. The main problems of vegetable oils, however, are their profile of essential fatty acids; most plants are unable to efficiently synthesize polyunsaturated fatty acids (PUFAs) such as docosahexaenoic acid (DHA) and eicosapentaenoic acid (EPA) [3]. Vegetable oils are mostly composed of PUFAs such as linoleic acid (LA) and alpha-linolenic acid (ALA) [2]. For these reasons, marine fish are considered to be the best source of polyunsaturated fatty acids. At the same time, scientists have proven that marine wild fish are able to accumulate high levels of polyunsaturated fatty acids by consuming marine organisms that have already synthesized these fatty acids, in other words DHA and EPA are biosynthesized mainly by phytoplankton, which are consumed by zooplankton and then by fish [4]. In this context, the single cell oil potential is highlighted in scientific literature.

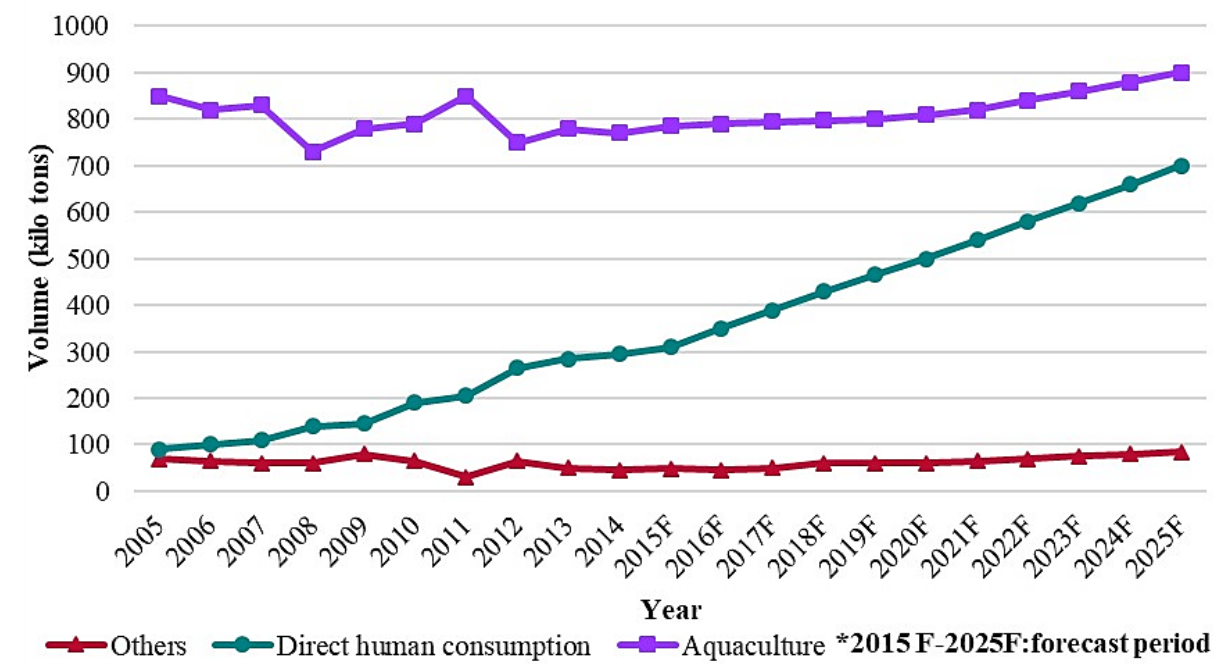

Fig. 1. Global consumption of fish oil [2].

Single cell oil (SCO) is oil obtained from oleaginous microorganisms like algae, protists and bacteria, yeast and other microscopic fungi. SCO has a significant advantage over oils obtained from plants or fish - it has a much higher content of PUFAs (omega-3) [2]. In the context of the circular economy, one of the strategies for sustainable waste management is the promotion and implementation of the idea that waste and by-products are considered as a resource. Biodegradable waste products and by-products, such as waste glycerol, cheese whey, wastes containing lignocellulose, etc. could be used in the production of SCO. The use of biodegradable waste products as a source of carbon in microbial cultivation can significantly reduce production costs, at the same time, value is added to residual products of agriculture and forestry. Furthermore, use of by-products as the main carbon source in the cultivation process enables treatment of generated waste streams, thus the negative impact on environment is reduced. The fact that the production of SCO is independent of location, climate and season, which is 
considered to be a problem for the production of vegetable oils, also makes SCO an attractive alternative. Depending on the purity of obtained SCO, its fatty acid profile and the extraction technologies used, it is possible to use SCO as a viable option in the production of essential fatty acids suitable for human nutrition or animal feed or as feedstock in the manufacture of biodiesel. However, production of SCO has several challenges, such as difficulty of finding the most suitable microorganisms, sources of nutrients, technology and growth conditions. Several microorganisms with an outstanding performance in lipid production belong to the class Labyrinthulomycetes. The production of SCO using species of Labyrinthulomycetes (in particular Schizochytrium) is commercialized, but little information is available about the success of using agricultural or industrial by-products in the commercial SCO production process [5], [6]. This review aims to overview the most progressive members of the class Labyrinthulomycetes in the context of SCO production. Also, an overview about application of biodegradable residues in Latvia is given.

\section{LiterATURE REVIEW}

\subsection{Use of Labyrinthulomycetes in Single Cell Oil Production}

Labyrinthulomycetes are unicellular members of stramenopilian protists commonly found in both marine and freshwater ecosystems all over the world [7]. The biomass of Labyrinthulomycetes in the oceanic water column could reaches up to $675 \times 103$ cells/L [8]. Labyrinthulomycetes species has an important role in nature as a decomposer, but in some cases these microorganisms are parasitic [8]. This group of microorganisms is characterized by a specific ectoplasmic net - an external cytoplasmic network (outside the cells) secreted by a specialized organelle called a bothrosome and multilamellate cell walls composed of Golgi body-derived scales [9]. Based on these recent classifications, Labyrinthulomycetes is subdivided into three groups - Labyrinthulids, Thraustochytrids and Amphitremids and more than 15 genera [8], [10]. This classification of Labyrinthulomycetes will also be used in this review. All three orders mainly are osmoheterotrophic in their mode of nutrition [7]. It should be noted that the possibility of producing SCO by using Thraustochytrid is explored more; less information is available about the potential use of strains belonging to the order of Labyrinthulids and Amphitremids. It is known that the majority of Thraustochytrids prefer salinities of $20 \%-34 \%$, and have a requirement for $\mathrm{Na}^{+}$ions that is not replaceable by $\mathrm{K}^{+}$ions, therefore, it is necessary to add sea water and, if necessary, additional sodium chloride and sea salts to the medium used for cultivation [7], [11], [12]. The fermentation of Labyrinthulomycete strains can be easily cultivated in a laboratory by baiting natural water samples with various organic rich components, for example, plant material and plating on nutrient rich agar, while antibiotics may be used to inhibit bacterial growth in samples [13]. Under laboratory conditions, the typical media for species of Labyrinthulomycetes are:

- Medium H (glucose $2 \mathrm{~g} / \mathrm{L}$, yeast extract $0.2 \mathrm{~g} / \mathrm{L}$, monosodium glutamate $0.5 \mathrm{~g} / \mathrm{L}$, agar 12 $\mathrm{g} / \mathrm{L}$, seawater till $1 \mathrm{~L}$ of media);

- dGPY-agar medium (glucose $2 \mathrm{~g} / \mathrm{L}$, polypeptone $1 \mathrm{~g} / \mathrm{L}$, yeast extract $0.5 \mathrm{~g} / \mathrm{L}$, agar $15 \mathrm{~g} / \mathrm{L}$ in sea water $500 \mathrm{ml}$ and distilled water $500 \mathrm{ml}$ );

- PYG-agar media (peptone $1.25 \mathrm{~g} / \mathrm{L}$, yeast extract $1.25 \mathrm{~g} / \mathrm{L}$, glucose $3 \mathrm{~g} / \mathrm{L}$, agar $15 \mathrm{~g} / \mathrm{L}$, seawater till $1 \mathrm{~L}$ of media);

- YPD (1 g/L yeast extract, $1 \mathrm{~g} / \mathrm{L}$ peptone, $5 \mathrm{~g} / \mathrm{L}$ glucose, $12 \mathrm{~g} / 1$ agar, thymine $2 \mathrm{ml}$ (100 $\mu \mathrm{g} / \mathrm{ml}$ ), antibiotics $200 \mathrm{mg}$ ampicillin/L, $100 \mathrm{mg}$ doxycycline/L) [9]. 
Optimal temperature and $\mathrm{pH}$ for Labyrinthulomycete cultivation may vary from $18{ }^{\circ} \mathrm{C}$ to $27^{\circ} \mathrm{C}$ (usually $20^{\circ} \mathrm{C}$ or $25^{\circ} \mathrm{C}$ ) and from 6.5 to 7 , respectively [13], [14]. Better biomass results are obtained by fermentation of microorganisms in bioreactors for several reasons. First - a better $\mathrm{pH}$ regulation, second - an improved oxygen supply. Conversion of saturated fatty acids to unsaturated fatty acids in Labyrinthylales cultures occurs more efficiently under conditions of abundant oxygen [15]. The most widely used carbon source for Labyrinthulomycete is glucose, but it is not sustainable and profitable to convert sugars into oils, optimally SCO production should avoid the use of synthetic media. However, whenever a by-product is used, additional nutrients must be added to ensure an optimal $\mathrm{C} / \mathrm{N}$ ratio. Oleaginous microorganisms accumulate lipids more efficiently under nitrogen-depleted conditions, Ryu et.al (2013) reported that, for example, Aurantiochytrium sp. achieves the highest biomass yield at $\mathrm{C} / \mathrm{N}$ ratio of $50-47.1 \mathrm{~g} / \mathrm{L}$, while at $\mathrm{C} / \mathrm{N}$ ratio of 35 and 20 , the obtained biomass was $45.2 \mathrm{~g} / \mathrm{L}$ and $31.8 \mathrm{~g} / \mathrm{L}$, respectively [16]. Also, Schizochytrium limacinum give the highest DHA yield at C/N ratios of 15, 20, 25 [17].

A study by Yokoyama et al (2007), in which SCO fatty acid profiles of 13 strains were analysed and the results of research conducted by other authors on 12 other strains were summarized, showed that strains such as Ulkenia amoeboidea SEK 214, Ulkenia sp. SEK 357, Aurantiochytrium sp. SEK 217 and Sicyoidochytrium sp. SEK 362 have high potential for producing essential fatty acids [18]. PUFA profiles of arachidonic acid (AA), EPA, docosatetraenoic acid (DTA), docosapentaenoic acid (DPA) and DHA were determined in this study. Biomass of Ulkenia amoeboid SEK 214 and several strains of Sicyoidochytrium contained more than $70 \%$ DHA, but the most significant amount of EPA was in the strains of Parietichytrium. Such results were obtained by culturing microorganisms in $\mathrm{H}$ medium for 2 to 3 days at $25{ }^{\circ} \mathrm{C}$ and then by incubating these strains in agar-dGPY medium for 7 to 10 days at $25^{\circ} \mathrm{C}$ [18]. It is also known from many other studies that Labyrinthulomycete can accumulate large amounts of essential fatty acids - more than $50 \%$ of total fatty acids and up to $25 \%$ of dry cell weight in some strains [13]. In the last decades a lot of efforts have been made to explore the most effective way to obtain omega-3 fatty acids from these microorganisms at lower costs. There are several factors affecting the obtained biomass yield and the accumulation of lipids, ranging from $\mathrm{pH}$, cultivation temperature, $\mathrm{C} / \mathrm{N}$ ratio, and duration of cultivation or lighting to type of flask or bioreactor used.

\subsection{Suitable Waste Products and By-products for Cultivation of Labyrinthulomycetes}

This chapter will only cover cases where biodegradable waste products have been used in the production of SCO. The most extensive research has been done on the use of crude glycerol as a substrate and Labyrinthulomycetes as a producer. An interesting study was done by Lung et al. - the experiment was conducted to determine the effects of cultivation modes and concentration of carbon sources (such as crude glycerol, pure glycerol and glucose) on biomass and SCO yield using Schizochytrium limacinum SR21 [19]. The best results were obtained with a crude glycerol concentration of $5 \%$, respectively, biomass yield $-7.39 \mathrm{~g} / \mathrm{L}$, total SCO yield $59.78 \%(4.42 \mathrm{~g} / \mathrm{L})$, DHA content of $141.89 \mathrm{mg} / \mathrm{g}$ or $24.72 \%$. Moreover, Schizochytrium limacinum SR21 completely utilized crude glycerol, which means that this strain effectively uses the crude glycerol as a nutrient, regardless of cultivation mode-mixotrophic, heterotrophic or mixo/heterotrophic [19]. Other studies have similar results when using crude glycerol as feedstock, Schizochytrium limacinum accumulated $50.6 \%$ of the lipids from the cell dry matter [20]. The advantage of crude glycerol is that small amounts of glycerol are sufficient to ensure optimal biomass growth. 
Alok Patel et al. (2019) showed that using lignocellulosic feedstock to cultivate the marine oleaginous microorganism Aurantiochytrium sp. T66 in SCO production is a viable idea and has great potential for industrial scale DHA production [15]. The use of birch hydrolysate achieved remarkable results - Aurantiochytrium sp. T66 cultivated in a bioreactor resulted in a biomass yield (cell dry weight) of $11.24 \mathrm{~g} / \mathrm{L}, 5.90 \mathrm{~g} / \mathrm{L}$ of SCO containing $35.76 \%$ DHA [15]. To provide the required amount of nitrogen in forest wood hydrolysate medium, along with artificial sea water the yeast extract (containing $9 \%-12 \%$ of total nitrogen) was added. In this study medium, a $\mathrm{C} / \mathrm{N}$ mass ratio of 10:1 was used. When cultivating Aurantiochytrium sp. T66 in the bioreactor, their stationary growth phase was reached after $72 \mathrm{~h}$. The stationary phase is the right time to harvest the biomass, as there is further risk that microorganisms will use the accumulated lipids for energy growth and biomass production. The major problem related to using hydrolysates as substrates is that raw material pre-treatment is energy intensive and high in terms of water consumption. The hydrolysis efficiency, even for modern technologies, does not exceed $60 \%$, respectively maximum $60 \%$ of the hardwood is converted into sugars [21]. The cost of hydrolysis consists of water, electricity, steam, enzyme, base solution and $\mathrm{H}_{2} \mathrm{SO}_{4}$ consumption [22]. Table 1 summarizes the results of various studies using Labyrinthulomycetes as SCO producers and biodegradable waste-products as feedstock.

TABLE 1. YIELD OF SCO OBTAINED USING LABYRINTHULOMYCETE AS PRODUCERS AND Biodegradable Waste-Products as FeEdstock

\begin{tabular}{llll}
\hline Species & Medium composition & $\begin{array}{l}\text { SCO content } \\
\text { (w/w \%o of biomass) }\end{array}$ & Reference \\
\hline Schizochytrium sp. S31 & Tofu whey wastewater, glucose, sea salt & 56.85 & {$[23]$} \\
$\begin{array}{l}\text { Schizochytrium limacinum } \\
\text { SR21 }\end{array}$ & Crude glycerol & 24.50 & {$[20]$} \\
Schizochytrium limacinum SR21 & Crude glycerol & 59.78 & {$[19]$} \\
Schizochytrium limacinum PA-968 & $\begin{array}{l}\text { Saline wastewater from demineralization of } \\
\text { cheese whey, glycerol, yeast extract }\end{array}$ & 46.26 & {$[24]$} \\
Saponochytrium marinum & $\begin{array}{l}\text { Saline wastewater from demineralization of } \\
\text { cheese whey, glycerol, yeast extract }\end{array}$ & 56.71 & {$[24]$} \\
Aurantiochytrium sp. T6 & Birch hydrolysate & 52.49 & {$[15]$} \\
Schizochytrium sp. & Sugarcane molasses & 41.20 & {$[25]$} \\
Schizochytrium limacinum & Sweet sorghum juice & 73.40 & {$[26]$} \\
Schizochytrium sp. DT3 & Enzyme saccharified hemp & 16.90 & {$[27]$} \\
Aurantiochytrium sp. & Spent yeast from brewery & 38.20 & {$[16]$} \\
Schizochytrium mangrovei & Food waste hydrolysate & 16.00 & {$[28]$} \\
\hline
\end{tabular}

In another study, tofu whey wastewater was found to provide better Schizochytrium sp. culture performance (higher biomass and DHA yield) compared to results obtained from three different conventional media [23]. Less efficient Schizochytrium mangrovei use the food waste hydrolysate derived from rice, noodles, meat, and vegetables, $14 \mathrm{~g} / \mathrm{L}$ of dry cell weight with $16 \%$ lipid content was obtained [28]. Countless other biodegradable waste products can be used as a feedstock for oleaginous microorganisms. Spalvins et al. have compiled information on more than 70 suitable biodegradable waste products classified into two large groups: industrial 
by-products and agricultural by-products [29]-[32]. These two groups are subdivided into smaller subgroups:

- industrial by-products include polymer rich sources, carbon compounds and sources for photosynthetic microorganisms [29], [30];

- agricultural by-products include monosaccharide and disaccharide rich sources, starch rich sources, structural polysaccharide rich sources and protein or lipid rich sources [31], [32].

\subsection{Suitable Waste Products and By-products for Cultivation of Labyrinthulomycetes in Latvia}

When selecting waste products or by-products to be used as carbon and energy sources for growth and lipid ac-cumulation, at least four factors must be considered: composition of waste products or by-products, com-position of pathogens in potential feedstock mass, financial possibilities, technological and technical capabilities.

\subsection{Crude Glycerol}

Crude glycerol is a major by-product of biodiesel production, it is affordable and suitable raw material that can be used in the fermentation process. The price of crude glycerol is reduced by undesirable compounds such as alcohol, heavy metals, soap, water and various salts. In addition, the market price of crude glycerol is currently affected by the fact that the crude glycerol supply is higher than demand [33], [19]. This situation is explained by the increase in biodiesel production fuelled by the introduction of climate policy in various countries around the world and the efforts to replace fossil fuels. In addition, refining crude glycerol for reuse in cosmetics, food or other industries is relatively expensive [29]. Pre-treatment of crude glycerol includes the addition of water to optimize viscosity, $\mathrm{pH}$ adjustment using chemicals, evaporation of methanol, water and ethanol, and filtration. In 2018, 88 thousand tonnes of biodiesel were produced in Latvia [34]. About one $\mathrm{kg}$ of crude glycerol is obtained from every $10 \mathrm{~kg}$ of biodiesel produced, so to calculate the estimated annual production of crude glycerol in Latvia, it is assumed that producing 88 thousand tonnes of biodiesel produces $10 \%$ of crude glycerol [35]. It follows from the above that in $2018,8.8$ thousand tonnes of crude glycerol were produced.

\subsection{Low-quality Wood}

Forests are one of the key natural resources in Latvia. On 1 January 2019, the forest area in Latvia occupied 3285 thousand hectares, $98 \%$ of which was forest stands, but the remaining 52 thousand hectares or $2 \%$ was defoliated stands, burning, windfall and cleaning [36]. More than $50 \%$ of the territory of Latvia is covered with forests [36]. Low-quality wood can be obtained in forests, it is wood (branches, bark, stumps, treetops, roots, damaged trees) that is not suitable for the manufacture of furniture, building materials, finishing materials or other products which require high-quality wood. Low-quality wood can also be used for energy purposes, but in this case a product with high added value is not produced. In the context of waste management, it is preferable to use residues to create new products rather than to use them for energy production purposes. The forestry and woodworking industries produce significant quantities of wood waste products such as sawmill slabs, saw dust, shavings, wood chips, bark, hogged wood, defective or damaged wood products. In 2018, the total amount of wood waste (non-hazardous) generated in Latvia was 75877 tonnes, most of which was sawdust, wood cuttings and damaged wood [37]. 
TABLE 2. ANNUAL WoOd WASte GENERATEd In LATVIA (2014-2018), TONNES [37]

\begin{tabular}{llllll}
\hline Waste class & $\mathbf{2 0 1 4}$ & $\mathbf{2 0 1 5}$ & $\mathbf{2 0 1 6}$ & $\mathbf{2 0 1 7}$ & $\mathbf{2 0 1 8}$ \\
\hline Wood & 166.5 & 111.7 & 1521.8 & 1898.7 & $\mathbf{3 5 1}$ \\
\hline $\begin{array}{l}\text { Wastes from woodworking, board and furniture manufacture } \\
\text { (sawdust, wood shavings, damaged wood and wood particles }\end{array}$ & 43774.1 & 83450.5 & 41835.9 & 27614.7 & $\mathbf{3 7 2 4 9 . 2}$ \\
not containing hazardous substances) & & & & & \\
\hline $\begin{array}{l}\text { Wood wastes from mechanical treatment of waste (sorting, } \\
\text { milling, compression, briquetting) not containing hazardous } \\
\text { substances }\end{array}$ & 429.7 & 442.3 & 5527.9 & 10645 & $\mathbf{2 9 ~ 8 4 7 . 7}$ \\
\hline Municipal wood waste not containing hazardous substances & 646.0 & 567.8 & 173.6 & 86.3 & $\mathbf{1 8}$ \\
\hline Wood packaging (crates, pallets) & 7688.2 & 5999.4 & 7061 & 5505.8 & $\mathbf{8 4 1 1 . 4}$ \\
\hline Total & $\mathbf{5 2 ~ 7 0 4 . 5}$ & $\mathbf{9 0 5 7 1 . 6}$ & $\mathbf{5 6 ~ 1 2 0 . 3}$ & $\mathbf{4 5 ~ 7 5 0 . 4}$ & $\mathbf{7 5 8 7 7 . 4}$ \\
\hline
\end{tabular}

\subsection{Dairy Waste}

The dairy industry generates large volumes of wastewater, including significant quantities of cheese whey. In the context of environmental protection, the disposal of cheese whey is challenging because of its high organic content [38]. The high presence of organic compounds is the reason why it is not recommended to irrigate agricultural land with raw cheese whey as a fertilizer. Cheese whey contains about $95 \%-92 \%$ water and 5\%-8\% dry matter (lactose, protein, minerals, vitamins, etc.) [38].

TABle 2. Approximate Composition of CheEse Whey [39]

\begin{tabular}{ll}
\hline Component & Percentage, $\%$ \\
\hline Lactose & $4.8-5$ \\
Protein & $0.15-0.22$ \\
Salts & $1-1.3$ \\
Organic acids & 0.20 \\
Water & $95-92$ \\
\hline
\end{tabular}

Every year, an average of 24 million tonnes of cheese is produced worldwide from which around 21.6 million tonnes of cheese whey results as a by-product, and when it comes to cheese production the European Union is a leader [40]. As there is no data available on the amount of cheese whey produced by cheese makers in Latvia, but it is known that about $90 \%$ of all milk used results in cheese whey, it is possible to determine the amount of cheese whey produced in Latvia [41]. In Latvia, milk production is an important economic sector, the dairy industry produced 47.4 thousand tonnes of cheese in 2018, the amount of cheese produced in Latvia is growing every year, and compared to 2010 the production increased by $53 \%$ (Fig. 2.) [42]. If it is assumed that $90 \%$ of the milk used in the production process results as cheese whey, in 2018 374 thousand tonnes of cheese whey were available. Cheese whey does not require specific pretreatment; however, it is necessary to meet the requirements for sterility and to remove large solid matter [39]. In order to reduce transport costs and environmental impacts, it would be reasonable to start SCO production business in an existing dairy or to create a symbiotic plant. At the same time, cheese whey is no longer treated simply as a waste product, but as a raw material for protein powder, which is widely used today. Potentially, protein powder production 
could be combined with SCO production, in other words deproteinised cheese whey could be used as a carbon source for Labyrinthulomycetes.

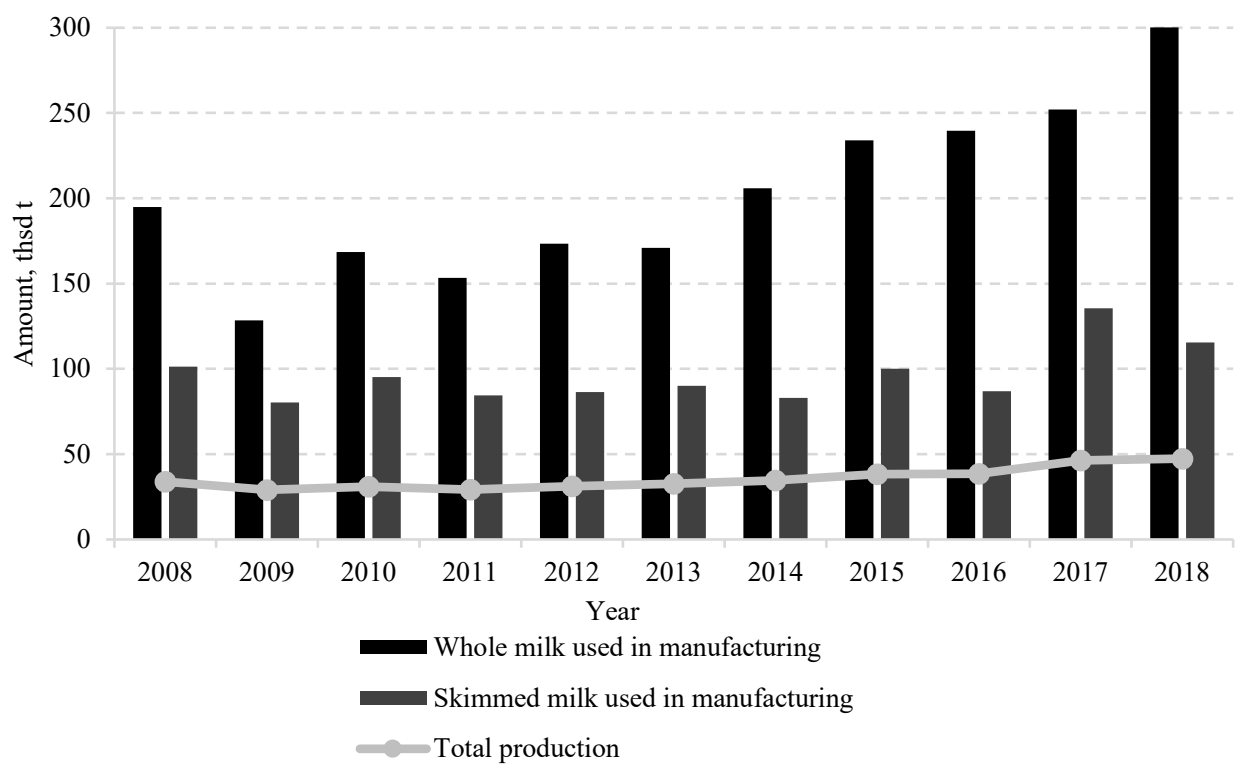

Fig. 2. Production of dairy products in Latvia [42].

\subsection{Brewery By-products}

By-products such as spent grain, spent yeast and spent hops/hot trub are obtained in the beer production process. Since these by-products contain high levels of protein, lignin and hemicellulose and often contain high levels of minerals and vitamins, it is suitable for the production of SCO. Additional hydrolysis of brewer's grain residues can increase the concentration of simple sugars (glucose, xylose), which are more easily converted into lipids by microorganisms, resulting in a higher SCO result. Currently spent grains are widely used in animal nutrition, however, the use of unprocessed by-products for direct animal feed must strictly comply with the food safety requirements that are regulated by Regulation (EC) No 183/2005 of the European Parliament and of the Council of 12 January 2005 [43]. These wastes are also suitable for biogas production. In 2018, 82 million litres of beer was produced in Latvia, and dozens of large and small breweries throughout the territory of Latvia are engaged in the production of beer [44]. The production of 100 litres of beer release approximately 14-20 $\mathrm{kg}$ of spent grain, $0.2-0.4 \mathrm{~kg}$ of hot trub and $1.5-3 \mathrm{~kg}$ of residual yeast [43]. It means that 11480 tonnes of spent grains, 164 tonnes of hot trub and 1230 tonnes of residual yeast are produced every year in Latvia.

\subsection{Fruit Waste}

Fruit residues obtained from the manufacture of juices and essential oils, containing fibre, are classified as lignocellulose rich waste [29]. Available information shows that $25-65 \%$ of the total quantity of fruit used in pressing juices constitutes pomace and juice pulps [29]. Lignocellulosic waste, as well as waste from the processing of fruit, is not suitable for use in 
animal feed because of its low digestibility and low protein content [29]. In 2018, juice producers in Latvia sold four million litres of fruit and vegetable juices and mixtures of juices [44]. Apple pomance contains simple sugars, carbohydrate (cellulose $128 \mathrm{~g} / \mathrm{kg}$ dry weight (DW), hemicellulose $44 \mathrm{~g} / \mathrm{kg}$ DW, lignin $24 \mathrm{~g} / \mathrm{kg} \mathrm{DW}$ ), pectin, crude fiber (51\% of dry biomas), proteins, vitamins and minerals [45]. A large producer of apple waste is the juice industry, apples contain about $50 \%$ of the juice and the remaining $50 \%$ is turned into waste [45]. Juice producers in Latvia sold 990193 litres of apple juices in 2018 [44]. In the context of CSO production, apples require simple pre-treatment (heating and filtration), but at the same time, they have a short shelf life.

\section{Multi-Criteria Analysis}

Multi-criteria analysis was carried out to determine which of the by-product alternatives is the most rational to use in Latvia for the production of single cell oil. In this work, the classical TOPSIS (Technique of Order Preference Similarity to the Ideal Solution) decision analysis method is used. After compiling data from official statistics of Latvia and scientific databases (mainly reports of experiments), six suitable by-products found in the Latvia are put forward for evaluation:

- Crude glycerol (from biodiesel production);

- Low quality wood;

- Dairy wastewater;

- Brewery by-products - spent grain;

- Brewery by-products - spent yeast;

- Apple waste from juice production.

In order to choose the best alternative, the following evaluation criteria are set: availability, price, required pre-treatment, processing efficiency and shelf life of agro-industrial by-products (see Table 3). The criterion of "required pre-treatment" considers how much energy is needed to process one tonne of raw material. In this way, the environmental impact is considered. As energy consumption may vary depending on the energy efficiency class of the equipment, treatment volumes and other factors, to evaluate the alternatives, the required pre-treatment process is rated from 1 to 5 (grades given by experts). The more energy-intensive pre-treatment is required, the higher mark received, i.e. in the context of single cell oil production, the alternative with the lowest mark in this criterion is preferred.

The "price" criterion presents the raw material cost, expressed in euros per tonne. The prices of specific by-products are determined based on Internet resources that reflect prices in Latvia and Lithuania, as well as consultations with industry representatives and experts. An essential aspect to consider when evaluating different biodegradable by-products is how much DHA can be produced from one tonne of feedstock. This value is included in the fourth criterion - process efficiency - and information about the necessary amount of by-products was sought in scientific literature, in the reports of experiments.

In large-scale production, the shelf life of feedstock plays an important role: the shorter shelf life is, the more difficult the production. If the alternative has short shelf life, it should be used quickly, and solutions such as freezing or cooling, which result in additional energy consumption and thus environmental impact, should be considered. In order to maintain objectivity, the shelf life of raw materials is determined for completely unprocessed material, for example, used brewer's yeast, which is not dried, is contaminated with other microorganisms within two days [46]. 
TABLE 3. INDICATORS AND WEIGHT USED IN MULTI-CRITERIA ANALYSIS

\begin{tabular}{lll}
\hline Criteria & Unit & Weight \\
\hline Local availability & tonnes per year & 0.247 \\
Price & EUR per tonne & 0.197 \\
Required pre-treatment & mark from 1 to 5 & 0.18 \\
Processing efficiency & kg per tonne & 0.19 \\
Shelf life of feedstock & days & 0.185 \\
& & 1 \\
\hline
\end{tabular}

Table 4 shows data that are used in the multicriteria analysis. Data were obtained from official statistics, scientific databases and by invited experts. At the same time, a number of reasonable assumptions were made. Apple waste - peel, seeds, pulp, stem, calyx - is rich in nutrients and could be considered as lignocellulosic waste. No experiments have been reported in the scientific database using apple waste as a nutrient for the micro-organism class Labyrinthulomycetes. But since the composition of apple waste and the potential hydrolysate composition is quite similar to that of orange waste hydrolysate, it is assumed that the same dry biomass, SCO and DHA yield is obtained using apple pulp [47]. The glucose yield ( $\mathrm{mg}$ glucose / $\mathrm{g}$ biomass) that can be obtained from low quality wood biomass may vary for different tree species. To determine how much biomass is needed to obtain 1 kilogram of SCO or DHA, the results of the Antczak et al. (2018) experiment are used, respectively, in the calculations of this work it is assumed that it is possible to obtain $602 \mathrm{mg}$ of glucose from one g of wood biomass [48].

TABLE 4. DATA USED IN MULTI-CRITERIA ANALYSIS

\begin{tabular}{lllllll}
\hline Feedstock & $\begin{array}{l}\text { Local } \\
\text { availability, } \\
\text { tonnes per } \\
\text { year }\end{array}$ & $\begin{array}{l}\text { Price, } \\
\text { EUR } \\
\text { per } \\
\text { tonne }\end{array}$ & $\begin{array}{l}\text { Required pre- } \\
\text { treatment, mark } \\
\mathbf{( 1 - 5 )}\end{array}$ & $\begin{array}{l}\text { Processing } \\
\text { efficiency, } \\
\text { DHA kg per } \\
\text { tonne of } \\
\text { substrate }\end{array}$ & $\begin{array}{l}\text { Shelf life of } \\
\text { feedstock, } \\
\text { days }\end{array}$ & Reference \\
\hline $\begin{array}{l}\text { Crude glycerol } \\
\text { Low quality }\end{array}$ & 8800 & 175 & 3 & 68.2 & 365 & {$[49],[50]$} \\
wood & 75877 & 42 & 5 & 42.2 & 730 & {$[15]$} \\
$\begin{array}{l}\text { Dairy } \\
\text { wastewaters }\end{array}$ & 374000 & 0 & 2 & 3.5 & 2 & {$[51]$} \\
$\begin{array}{l}\text { Spent grain } \\
\text { Spent yeast }\end{array}$ & 11480 & 150 & 2 & 6.2 & 2 & {$[52]$} \\
Apple waste & 1230 & 150 & 3 & 83.2 & 2 & {$[16]$} \\
\hline
\end{tabular}

In the context of SCO and polyunsaturated fatty acids production, in Latvia, preference should be given to used dairy wastewater or whey (stable first place with a value of closeness to ideal solution of 0.57 ). The next most suitable raw material is low quality wood, followed by 3 waste products with almost identical results: raw glycerol, spent yeast from brewery and apple waste, with the relative closeness to ideal solution $0.33,0.31,0.30$, respectively (see Fig. 3 ). The results show that the most unsuitable by-product are grain residues from brewery industry with value of closeness to ideal solution 0.18 . It can be concluded that further research and experiments should optimize the growth of Labyrinthulomycetes class microorganisms and DHA biosynthesis using dairy wastewater, low quality wood and raw glycerol. 


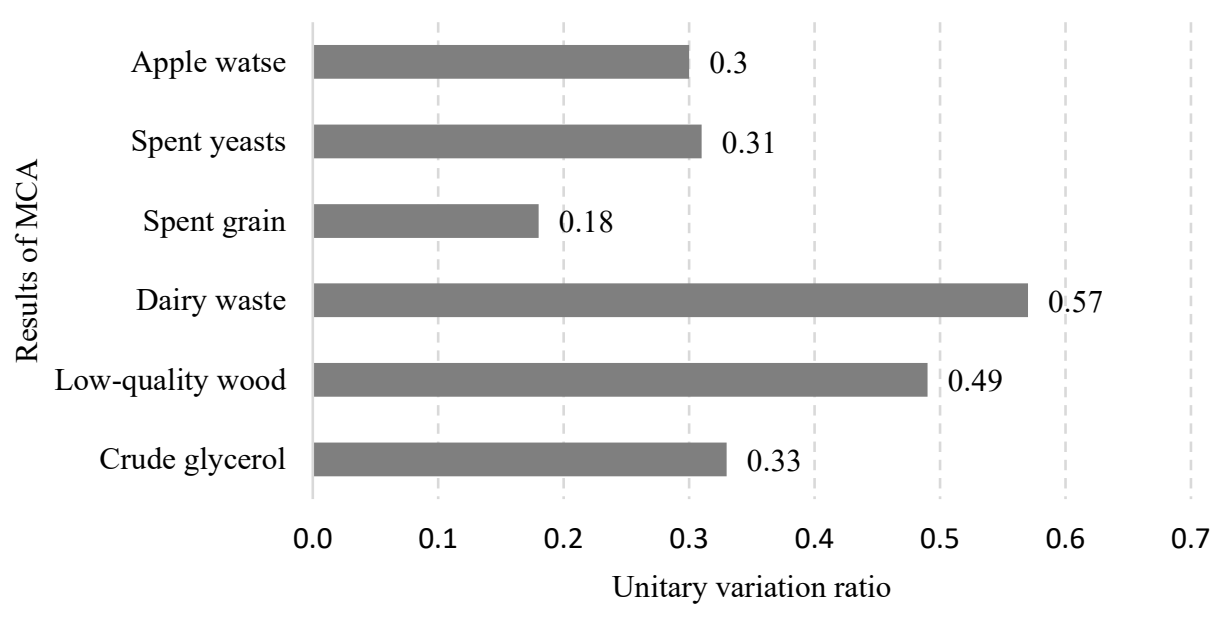

Fig. 3. Relative closeness to the ideal solution with TOPSIS method.

\section{Conclusions}

The microorganisms of the Labyrinthulomycetes class are special with their ability to synthesize large amounts of long chain polyunsaturated fatty acids, for this reason, it is appropriate to use single cell oil obtained from Labyrinthulomycetes as a component of human food and animal feed. Huge attention has been given to the potential of Thraustochytrids (to synthesize lipids with high levels of essential polyunsaturated fatty acids), but less research has been conducted on other order of Labyrinthulomycetes, i.e. Labyrinthulids and Amphitremids. More research needs to be done in the field of single cell oil production with Labyrinthulids and Amphitremids.

Several suitable biodegradable waste and by-products are widely available in Latvia. Currently, biodegradable waste products, if not landfilled, are mainly used for animal feed, biogas production or composting. Considering the significant potential to produce a high-value-added product that would benefit the overall national economy and the principles of sustainable waste management, practical experiments must be carried out to select the appropriate strain of microorganims and processing technology. There is relatively little information on the use of waste products (excluding crude glycerol) in the production of single cell oil with Labyrinthulomycetes, so extensive research is needed in this field. In Latvia, the focus should be on experiments using by-products of dairy industry (for polyunsaturated fatty acids production), in parallel, to determine the potential of other by-products, experiments using feedstock not previously mentioned in the scientific literature are needed.

\section{ACKNOWLEDGEMENT}

The work has been supported by ERAF project KC-PI-2017/60 "Supercritical Omega-3 oil from production by-products" managed by the Investment and Development Agency of Latvia (LIAA). 


\section{REFERENCES}

[1] FAO. The State of World Fisheries and Aquaculture 2018. Meeting the sustainable development goals. Rome, 2018.

[2] de O. Finco A. M., Mamani L. D. G., de Carvalho J. C., de Melo Pereira G. V., Thomaz-Soccol V., Soccol C. R. Technological trends and market perspectives for production of microbial oils rich in omega-3. Critical Reviews in Biotechnology 2017:37(5):656-671. https://doi.org/10.1080/07388551.2016.1213221

[3] Spalvins K., Blumberga D. Production of Fish Feed and Fish Oil from Waste Biomass Using Microorganisms: Overview of Methods Analyzing Resource Availability. Environmental and Climate Technology 2018:22(1):149-164 https://doi.org/10.2478/rtuect-2018-0010

[4] Spolaore P., Joannis-Cassan C., Duran E., Isambert A. Commercial applications of microalgae. J. Biosci. Bioeng. 2006:101(2):87-96. https://doi.org/10.1263/jbb.101.87

[5] Wong M. K. M., Tsui C. K. M., Au D. W. T., Vrijmoed L. L. P. Docosahexaenoic acid production and ultrastructure of the thraustochytrid Aurantiochytrium mangrovei MP2 under high glucose concentrations. Mycoscience 2008:49(4):266270. https://doi.org/10.1007/S10267-008-0415-7

[6] Ward O. P., Singh A. Omega-3/6 fatty acids: Alternative sources of production. Process Biochemistry 2005:40(12):36273652. https://doi.org/10.1016/j.procbio.2005.02.020

[7] Raghukumar S. Ecology of the marine protists, the labyrinthulomycetes (Thraustochytrids and labyrinthulids). European Journal of Protistology 2002:38(2):127-145. https://doi.org/10.1078/0932-4739-00832

[8] Takahashi Y., Yoshida M., Inouye I., Watanabe M. M. Diplophrys mutabilis sp. nov., a New Member of Labyrinthulomycetes from Freshwater Habitats. Protist 2014:165(1):50-65. https://doi.org/10.1016/j.protis.2013.10.001

[9] Tsui C. K. M. Labyrinthulomycetes phylogeny and its implications for the evolutionary loss of chloroplasts and gain of ectoplasmic gliding. Molecular Phylogenetics and Evolution 2009:50(1):129-140. https://doi.org/10.1016/j.ympev.2008.09.027

[10] Pan J., del Campo J., Keeling P. J. Reference Tree and Environmental Sequence Diversity of Labyrinthulomycetes. Journal of Eukaryotic Microbiology 2017:64(1):88-96. https://doi.org/10.1111/jeu.12342

[11] Alderman D. J., Gareth Jones E. B. Physiological requirements of two marine phycomycetes, Althornia crouchii and Ostracoblabe implexa. Transactions in the British Mycological Society 1971:57(2):213-IN3. https://doi.org/10.1016/S0007-1536(71)80003-7

[12] Goldstein S. Development and Nutrition of New Species of Thraustochytrium. American Journal of Botany 1963:50(3):271-279, Mar. 1963. https://doi.org/10.1002/j.1537-2197.1963.tb12234.x

[13] Allemann M. N., Allen E. E. Characterization and Application of Marine Microbial Omega-3 Polyunsaturated Fatty Acid Synthesis. Methods in Enzymology 2018:605:3-32. https://doi.org/10.1016/bs.mie.2018.02.018

[14] Ochsenreither K., Glück C., Stressler T., Fischer L., Syldatk C. Production Strategies and Applications of Microbial Single Cell Oils. Frontiers in Microbiology 2016:7:1539. https://doi.org/10.3389/fmicb.2016.01539

[15] Patel A., Rova U., Christakopoulos P., Matsakas L. Simultaneous production of DHA and squalene from Aurantiochytrium sp. grown on forest biomass hydrolysates. Biotechnology for Biofuels 2019:12(1). https://doi.org/10.1186/s13068-019-1593-6

[16] Ryu B. G., Kim K., Kim J., Han J. I., Yang J. W. Use of organic waste from the brewery industry for high-density cultivation of the docosahexaenoic acid-rich microalga, Aurantiochytrium sp. KRS101. Bioresource Technology 2013:129:351-359. https://doi.org/10.1016/j.biortech.2012.11.049

[17] Sahin D., Tas E., Altindag U. H. Enhancement of docosahexaenoic acid (DHA) production from Schizochytrium sp. S31 using different growth medium conditions. AMB Express 2018:8(1):78. https://doi.org/10.1186/s13568-018-0540-4

[18] Yokoyama R., Salleh B., Honda D. Taxonomic rearrangement of the genus Ulkenia sensu lato based on morphology, chemotaxonomical characteristics, and 18S rRNA gene phylogeny (Thraustochytriaceae, Labyrinthulomycetes): Emendation for Ulkenia and erection of Botryochytrium, Parietichytrium. Mycoscience 2007:48(6):329-341. https://doi.org/10.1007/S10267-007-0377-1

[19] Lung Y. T., Tan C. H., Show P. L., Lam H. L., Lan J. C. W. Docosahexaenoic acid production from crude glycerol by schizochytrium limacinum SR21. Chemical Engineering Transactions 2015:45:967-972. https://doi.org/10.3303/CET1545162

[20] Pyle D. J., Garcia R. A., Wen Z. Producing docosahexaenoic acid (DHA)-rich algae from biodiesel-derived crude glycerol: Effects of impurities on DHA production and algal biomass composition. J. Agric. Food Chem. 2008:56(11):3933-3939. https://doi.org/10.1021/jf800602s

[21] Wei L., Pordesimo L. O., Batchelor W. D. Ethanol production from wood: Comparison of hydrolysis fermentation and gasification biosynthesis. ASABE Annu. Int. Meet. Tech. Pap., 2007. https://doi.org/10.13031/2013.23658

[22] Chen W. H., Jang M. F., Jheng S. L., Lo C. J., Wang W. Cellulosic sugars from biomass: Effect of acid presoaking on pretreatment efficiency and operating cost estimation for sugar production. Bioresource Technology Reports 2019:7:100259. https://doi.org/10.1016/j.biteb.2019.100259

[23] Wang S. K., Wang X., Tian Y. T., Cui Y. H. Nutrient recovery from tofu whey wastewater for the economical production of docosahexaenoic acid by Schizochytrium sp. S31. Science of the Total Environment 2020:710:136448. https://doi.org/10.1016/j.scitotenv.2019.136448 
[24] Humhal T., Kastanek P., Jezkova Z., Cadkova A., Kohoutkova J., Branyik T. Use of saline waste water from demineralization of cheese whey for cultivation of Schizochytrium limacinum PA-968 and Japonochytrium marinum AN4. Bioprocess and Biosystems Engineering 2017:40(3):395-402. https://doi.org/10.1007/s00449-016-1707-5

[25] Ren L. J., Li J., Hu Y. W., Ji X. J., Huang H. Utilization of cane molasses for docosahexaenoic acid production by Schizochytrium sp. CCTCC M209059. Korean Journal of Chemical Engineering 2013:30(4):787-789. https://doi.org/10.1007/s11814-013-0020-0

[26] Liang Y., Sarkany N., Cui Y., Yesuf J., Trushenski J., Blackburn J. W. Use of sweet sorghum juice for lipid production by Schizochytrium limacinum SR21. Bioresource Technology 2010:101(10):3623-3627. https://doi.org/10.1016/j.biortech.2009.12.087

[27] Gupta A., Abraham R. E., Barrow C. J., Puri M. Omega-3 fatty acid production from enzyme saccharified hemp hydrolysate using a novel marine thraustochytrid strain. Bioresource Technology 2015:184:373-378. https://doi.org/10.1016/j.biortech.2014.11.031

[28] Pleissner D., Lam W. C., Sun Z., Lin C. S. K. Food waste as nutrient source in heterotrophic microalgae cultivation. Bioresource. Technology 2013:137:139-146. https://doi.org/10.1016/j.biortech.2013.03.088

[29] Spalvins K., Zihare L., Blumberga D. Single cell protein production from waste biomass: Comparison of various industrial by-products. Energy Procedia 2018:147:409-418. https://doi.org/10.1016/j.egypro.2018.07.111

[30] Spalvins K., Vamza I., Blumberga D. Single Cell Oil Production from Waste Biomass: Review of Applicable Industrial By-Products. Environmental and Climate Technologies 2019:23(2):325-337. https://doi.org/10.2478/rtuect-2019-0071

[31] Spalvins K., Vamza I., Blumberga D. Single cell oil production from waste biomass: Review of applicable industrial byproducts. Environmental and Climate Technologies 2019:23(3):325-337. https://doi.org/10.2478/rtuect-2019-0071

[32] Spalvins K., Zihare L., Blumberga D. Single cell protein production from waste biomass: comparison of various industrial by-products. Energy procedia 2018:147:409-418. https://doi.org/10.1016/j.egypro.2018.07.111

[33] Quispe C. A. G., Coronado C. J. R., Carvalho J. A. Glycerol: Production, consumption, prices, characterization and new trends in combustion. Renewable and Sustainable Energy Reviews 2013:27:475-493. https://doi.org/10.1016/j.rser.2013.06.017

[34] Energy balance, in natural units (NACE Rev.2) | Central Statistical Bureau of Latvia. [Online]. [Accessed: 29.12.2019]. Available: https://www.csb.gov.lv/lv/statistika/statistikas-temas/videenergetika/energetika/tabulas/eng010/energobilance-naturalas-mervienibas-nace-2-red.

[35] Kumar L. R., Kaur R., Yellapu S. K., Zhang X., Tyagi R. D. Biodiesel Production From Oleaginous Microorganisms With Wastes as Raw Materials", in Biofuels: Alternative Feedstocks and Conversion Processes for the Production of Liquid and Gaseous Biofuels, Elsevier, 2019. https://doi.org/10.1016/B978-0-12-816856-1.00027-0

[36] Central Statistical Bureau of Latvia. Environment of Latvia in Figures: Climate Change, Natural Resources and Environmental Quality in 2018. Riga, 2019.

[37] LVG̣MC. Latvian Environment, "Review '3-Atkritumi,"” $2019 . \quad$ [Online]. Available: http://parissrv.lvgmc.lv/\#viewType=reportIndexView\&addrefreshtimer=true\&donotrenderwithoutrole=true \&donotusew rapper $=$ true \&type $=3 \mathrm{WA} \&$ incrementCounter $=1$. [Accessed: 13-May-2020].

[38] Seo Y. H., Lee I., Jeon H., Han J.-I. Efficient conversion from cheese whey to lipid using Cryptococcus curvatus. Biochemical Engineering Journal 2014:90:149-153. https://doi.org/10.1016/j.bej.2014.05.018

[39] Carota E., Crognale S., D’Annibale A., Gallo A. M., Stazi S. R., Petruccioli M. A sustainable use of Ricotta Cheese Whey for microbial biodiesel production. Science of the Total Environment 2017:584-585:554-560. https://doi.org/10.1016/j.scitotenv.2017.01.068

[40] U. Quantiy in Tonnes. Milk Market Observatory Production of Dairy products in the TOTAL CHEESE. 2018.

[41] Santonja G. G., Karlis P., Stubdrup K. R. Best Available Techniques (BAT) Reference Document for the Food, Drink and Milk Industries. 2010.

[42] Central Statistical Bureau of Latvia. Production of dairy products. [Online]. [Accessed: 08.12.2019]. Available: https://www.csb.gov.lv/lv/statistika/statistikas-temas/lauksaimnieciba/lopkopiba/tabulas/llg112/piena-produkturazosana.

[43] dos S. Mathias T. R., de Aguiar P. F., de A. Silva J. B., de Mello P. P. M., Sérvulo E. F. C. Brewery Wastes Reuse for Protease Production by Lactic Acid Bacteria Fermentation. Food Technol. Biotechnol. 2017:55(2):218-224. https://doi.org/10.17113/ftb.55.02.17.4378

[44] Central Statistical Bureau of Latvia, RUG010. Sale of manufactured industrial products (summary of selected code groups of the PRODCOM classification), 2019. [Online]. [Accessed: 12.04.2020]. Available: http://data1.csb.gov.lv/pxweb/en/rupnbuvn/rupnbuvn_rupn_ikgad/RUG010.px/table/tableViewLayout1/.

[45] Catană M., Catană L., Lazăr M. A., Lazăr A. G., Teodorescu R. I., Asănică A. C., Belc N. Achieving of functional ingredient from apple wastes resulting from the apple juice industry. AgroLife Scientific Journal 2018:7(1):9-17.

[46] Jacob F. F., Striegel L., Rychlik M., Hutzler M., Methner F.-J. Spent Yeast from Brewing Processes: A Biodiverse Starting Material for Yeast Extract Production. Fermentation 2019:5(2):51. https://doi.org/10.3390/fermentation5020051

[47] Park W. K., Moon M., Shin S. E., Cho J. M., Suh W. I., Chang Y. K., Lee B. S. Economical DHA (Docosahexaenoic acid) production from Aurantiochytrium sp. KRS101 using orange peel extract and low cost nitrogen sources. Algal Research 2018:29:71-79. https://doi.org/10.1016/j.algal.2017.11.017 
[48] Antczak A., Marchwicka M., Szadkowski J., Drożdżek M. Sugars Yield Obtained after Acid and Enzymatic Hydrolysis of Fast-growing Poplar Wood Species. BioResources 2018:13(4). https://doi.org/10.15376/biores.13.4.8629-8645

[49] Scott S. D., Armenta R. E., Berryman K. T., Norman A. W. Use of raw glycerol to produce oil rich in polyunsaturated fatty acids by a thraustochytrid. Enzyme and Microbial Technology 2011:48(3):267-272. https://doi.org/10.1016/j.enzmictec.2010.11.008

[50] INSIGHT: Europe glycerine spot prices post triple-digit rises on fears of further biodiesel output cuts | ICIS. [Online]. [Accessed: 13.05.2020]. Available: https://www.icis.com/explore/resources/news/2020/04/03/10490229/europ e-glycerine-spot-prices-post-triple-digit-rises-on-fears-of-further-biodiesel-output-cuts.

[51] Sara P., Cacheira I., Luís André Roque Fortes. MSc Thesis in Biological Engineering "Heterotrophic cultivation of Thraustochytrids using glycerol and saline medium from a dairy effluent", Universidade do Algarve 2016.

[52] Fani K. W., Chen F., Jonesi E. B. G., Vrijmoedi L. L. P. Utilization of food processing waste by Thraustochytrids, 2000. 